\title{
Extraction of gluten from food material
}

\begin{abstract}
Food allergies are creating many problems even though the total population allergic to certain proteins in food is less than $1 \%$. Gluten is one among the major proteins present in almost all kinds of flours, especially in wheat and barley in higher quantities. Food industries are now a day's turning towards producing gluten free foods which can be consumed by all. In order to produce them we must know various concentrations of gluten present in them. The aim of the present study is to extract, quantify and estimate the gluten present in materials like wheat, barley, maida, and oats. By this data the effect of gluten related allergies can be studied.
\end{abstract}

\author{
Volume 7 Issue 3 - 2018 \\ Sreenivas Reddy Bathula, ${ }^{1,2}$ Ravishankar BV, ${ }^{3}$ \\ Pujar Basayya Gullaya ${ }^{3}$ \\ 'Adama Science \& Technology University, Ethiopia \\ ${ }^{2}$ Savi Easy Life sro, Czech Republic \\ ${ }^{3}$ Department of Biotechnology, Bapuji Institute of Engineering \\ and Technology, India
}

Correspondence: Sreenivas Reddy Bathula, Adama Science \& Technology University, PO Box 1888, Adama, Ethiopia, Tel +91959I-2402 34,Email jaishwa@hotmail.com

Received: December 13, 2017 | Published: June 22, 2018

\section{Introduction}

\section{Gluten}

Primarily, "gluten" (from Latin for "glue") has been defined as "the rubber-like proteinaceous mass that remains, when wheat dough is washed with water or salt solution to remove soluble constituents and starch granules". The procedure of wheat gluten preparation was first described by Beccari in 1745 and is nowadays widely used for the industrial isolation of "vital gluten", a byproduct of wheat starch production. Gluten is a protein fraction from wheat, maida, barley, oats or their crossbred varieties and derivatives thereof, to which some people are intolerant and that is insoluble in water and $0.5 \mathrm{M}$ $\mathrm{NaCl}$. These proteins that naturally occur in a prohibited grain and that may cause adverse health effects in persons in celiac disease. Some food processing procedures increase gluten's solubility, but do not necessarily diminish the protein fraction's harmful effect. ${ }^{1-5}$

Gluten can be readily prepared by gently washing dough under a stream of running water. This removes the bulk of the soluble and particulate matter to leave a proteinaceous mass that retains its cohesiveness on stretching. Gluten comprises some $75 \%$ protein on a dry weight basis, with most of the remainder being starch and lipids. Furthermore, the vast majority of the proteins are of a single type called prolamins. Prolamins are a group of proteins that were initially defined based on their solubility in alcohol-water mixtures, typically $60-70 \%(\mathrm{v} / \mathrm{v})$ ethanol. This definition has since been extended to include related proteins, which are not soluble in alcohol-water mixtures in the native state, owing to their presence in polymers stabilized by interchain disulphide bonds. In wheat, these groups of monomeric and polymeric prolamins are known as gliadins and glutenins, respectively, and together form gluten.

As a result of the formation of a protein matrix, individual cells of wheat flour contain networks of gluten proteins, which are brought together during dough mixing. The precise changes that occur in the dough during mixing are still not completely understood, but an increase in dough stiffness occurs that is generally considered to result from 'optimization' of protein-protein interactions within the gluten network. In molecular terms, this 'optimization' may include some exchange of disulphide bonds as mixing in air, oxygen and nitrogen result in different effects on the sulphydryl and disulphide contents of dough. The natural fate of the wheat grain is not to provide flour for humankind but to germinate to produce a new plant. The biological role of the gluten protein is, therefore, to provide a store of carbon, nitrogen and sulphur to support seed germination and seedling growth. The gluten proteins have no other known biological role and their viscoelastic properties appear to be a purely fortuitous consequence of their sequences and interactions.

Glutenins and gliadins are the most important proteins in the wheat grain which can be used for assessing genetic diversity of species or varieties and for genotype identification in different wheat species. Glutenin subunits are divided into two major groups according to their electrophoretic mobility in SDS-PAGE, the high molecular weight (HMW) and low molecular weight (LMW) glutenin subunits.

\section{Allergic nature of gluten}

Demonstrating intolerance to gluten is a complex endeavour. The toxicity of gluten in celiac disease (CD) stems from an immune response involving both innate and adaptive systems. No model is available to replicate the response, although rhesus macaques were recently proposed. The demonstration of gluten intolerance depends on in vivo challenge studies.

$\mathrm{CD}$ has a highly variable presentation and symptoms are considered unreliable as an indicator of active disease. The defining indicator of gluten-induced damage in $\mathrm{CD}$ is histopathology of the mucosa of the small intestine. It only develops in response to ongoing gluten exposure, which means the investigation of gluten intolerance faces design and ethical hurdles. Other factors associated with CD hinder representative studies. They include the heterogeneous presentation of disease, a high rate of under diagnosis and the lifestyle challenges of a truly Gluten Free (GF) diet. ${ }^{6-9}$

\section{Defining gluten-free foods}

In many circles, a zero tolerance approach to gluten in GF foods is considered impractical. With derivatives of wheat, and to a lesser extent barley, used widely in mainstream food channels, GF foods are susceptible to contamination, even when produced in dedicated facilities. Some GF foods in Europe are even based on wheat-starch which, though processed to remove gluten, contains gluten residues. However, many GF foods are entirely free of gluten containing grains 
and they are available throughout Europe. The FDA recently proposed draft GF standards for the first time, which are based on final gluten content. Codex is in the final stages of approving similar standards. The draft standards permit trace gluten in GF foods, but aim to keep total dietary gluten well below levels generally accepted as safe for $\mathrm{CD}$ patients. They allow ingredients derived from gluten-containing grains in the foods, providing the ingredients have been processed to remove gluten and prescribed limits are met.

In addition, Codex has had standards since 1981, which define GF foods according to the nitrogen content of raw ingredients. These standards are only applicable to GF foods with ingredients derived from wheat, barley or rye. The Codex has endorsed the R5-ELISA as a means of upholding GF standards based on final gluten content. The FDA has tentatively endorsed the method and acknowledges that future methods including other ELISAs, may prove useful in the area. In light of such significant endorsement, it is important to consider the remaining limitations of gluten analysis by ELISA. ${ }^{10-15}$

\section{The basis for allergicity of gluten's}

In vitro, and to a lesser extent, in vivo methods have been useful in dissecting the basis for gluten's immune-toxicity. Activation of CD4 (+) T cells in the small intestinal mucosa by gluten peptides released by digestive enzymes is a key event in $\mathrm{CD}$. A direct effect from other gluten peptides on the intestinal epithelium has a role in inflammation. Auto-antibodies are associated with active $\mathrm{CD}$ and their role in pathogenesis is currently an active area of research. Multiple peptides are implicated in $\mathrm{T}$ cell stimulation, present in both major fractions of gluten (in wheat these fractions are the gliadins and glutenins). A single peptide located within a region resistant to digestive enzymes is the immune dominant portion of the gluten sub fraction, $\alpha$-gliadin, at least in adult patients.

The full potency of this peptide is dependent on its modification by a tissue trans glutaminase within the intestinal mucosa. The enzyme introduces a negative charge into the peptide, which enhances class II MHC binding on antigen-presenting cells. The crucial role of $\mathrm{T}$ cell activation in disease pathogenesis is evident from the association of CD with class II MHC genotype. Over $90 \%$ of patients are positive for the HLA DQ2 heterodimer with the remainder positive for HLA DQ8. The peptides stimulatory to T cells in HLA DQ8 individuals appear to be distinct from those of the HLA DQ2 model.

\section{Celiac disease (CD)}

Celiac disease (CD) is an immune mediated inflammatory disease of the upper small intestine in genetically susceptible individuals triggered by the ingestion of the storage proteins (gluten) from wheat, rye, barley, and possibly oats. Intestinal symptoms similar to the clinical picture of CD nowadays were already described in the Roman Empire in the second century AD, and the idea that the disorder may be associated with food ingestion was discovered in the nineteenth century. Yet it was not until the 1950s that gluten was identified as the precipitating factor of $\mathrm{CD}$, and a gluten-free diet was successfully introduced as treatment. For a long time, $\mathrm{CD}$ was considered to be a rare childhood enteropathy. Thanks to modern diagnostic techniques and increased awareness, epidemiological studies of the past decade revealed that $\mathrm{CD}$ is one of the most frequent food intolerances in many parts of the world, affecting about $1 \%$ of the population. While CD is typically characterized by a flat intestinal mucosa with villous atrophy resulting in a generalized malabsorption of nutrients, the spectrum of clinical manifestations is very complex, including silent and atypical presentations as well as numerous extra intestinal symptoms and nonspecific findings. This is why many cases remain undiagnosed and entail the risk of long-term complications such as osteoporosis, anemia, or malignancy in addition to a substantial burden of illness. Strategies like raising awareness and screening in at risk groups have been successful in identifying previously undiagnosed patients, but the risks and benefits of screening the general population for $\mathrm{CD}$ remain controversial.

In addition to medical sciences like pediatrics, pathology, immunology, gastroenterology, neurology, and dermatology, other sciences like pharmaceutics, analytical and food chemistry, food technology, cereal breeding, genetic engineering, and law are involved in $\mathrm{CD}$ and gluten research. Over the past few decades' tremendous progress has been made in elucidating the complex pathomechanism of $\mathrm{CD}$, which involves an intricate interplay of gluten, other environmental factors, genetics, and immunity. The strong association between HLADQ2/8 alleles and CD development has been proven conclusively, but the relative contributions of other unknown genetic risk factors and environmental factors such as infections, timing of gluten introduction into the infants' diet, and standards of hygiene have yet to be evaluated. Beside $\mathrm{CD}$, other related disorders like dermatitis herpetiformis, gluten ataxia, wheat allergy, irritable bowel syndrome, and non-celiac gluten sensitivity are included as well as associated genetic and autoimmune diseases. The onset of CD may occur at any age, and the majority of patients nowadays present with predominantly extra intestinal complaints. This diagnostic challenge has been met with improved serological tests and HLADQ genotyping, but small intestinal biopsy is still considered the gold standard. Recent advances have been made in understanding the steps in the pathomechanism of $\mathrm{CD}$, beginning with gluten intake and digestion followed by epithelial passage and induction of the adaptive and innate immune responses with each advance in understanding within the single steps, new questions have arisen that will need to be investigated. As probably the only autoimmune disease in which the triggering environmental factor (gluten) is known, CD may serve as a unique model of autoimmunity that may be transferred to other immune-mediated diseases. ${ }^{16-19}$

This literature gives an overview on cereals and provides an indepth description of cereal proteins. The storage proteins of all cereals have a very intricate composition with hundreds of single proteins. When comparing the amino acid sequences, there are distinct differences between the $\mathrm{CD}$ toxic storage proteins from wheat, rye, barley, and oats and the $\mathrm{CD}$ safe storage proteins from corn, rice, sorghum, and millet. Advances in DNA and RNA sequencing have contributed to an increased knowledge of protein structures, which helps identify CD-toxic epitopes. Testing for CD toxicity may be done in vivo or in vitro using cereal flours or extracts, protein fractions, protein types, single proteins, or peptides. Whereas prolamins from wheat with an emphasis on $\alpha$-gliadins and avenins have been studied most thoroughly regarding their $\mathrm{CD}$ toxicity, little is known about prolamins from rye and barley and all glutelins. CD epitopes are derived from all protein types from wheat, rye, barley, and oats and further research on these proteins will help identify more relevant structures and allow an assessment of toxicity levels.

The treatment of $\mathrm{CD}$ includes both conventional and alternative therapies. The conventional treatment, a strict, lifelong gluten-free diet, is currently the only safe option available. Patients adhering to a gluten- 
free diet need to be followed up for an assessment of improvement of symptoms and recovery of normal intestinal architecture, not least because of the risk of refractory $\mathrm{CD}$. Compliance to the gluten-free diet is essential not only to prevent a recurrence of symptoms, but also to reduce the risk of complications. An assessment of nutritional status is recommended at regular intervals, and monitoring the health related quality of life of $\mathrm{CD}$ patients may help identify factors for its improvement. Alternative therapeutic options such as oral enzyme therapy, permeability inhibitors, inhibition of trans glutaminase 2 , HLA-DQ blocking, modulation of inflammation and vaccination are in various stages of development and may become promising strategies. As more and more steps in the pathomechanism of CD are unraveled, further interesting approaches for alternative treatments will arise..$^{20-28}$

The main objective of this work is to extract the gluten from different food feedstocks, to estimate the amount of gluten present in different food feedstocks. It could make people aware of what is gluten, where is gluten found in food, beverages, cosmetics, and medications, who needs to avoid it, and why?

\section{Materials and methods}

Extraction of gluten from the wheat flour, maida, barley and oats was done by entrapping the gluten proteins in a cheese cloth and the amount of gluten proteins was estimated from the sample.

Weigh $50 \mathrm{~g}$ powder of each food material was mixed with $50 \mathrm{~m}$ of distilled water in bowl and keep it for one hour. Food materials transferred into cheese cloth and washed it using running tap water until white turbidity goes out. Gluten is present inside the cheese cloth. Weighed empty petridish and collect gluten from cheese cloth. Collected gluten from cheese cloth is placed in petridish and takes weight of petridish with gluten. Keep petridish in hot air oven for drying at $105{ }^{\circ} \mathrm{C}$ for two hours. Make gluten into small pieces and Keep it for another $30 \mathrm{~min}$. After drying make dry gluten into powder using pestle and motar.

Weigh $20 \mathrm{mg}$ of all those glutens in powdered form using weighing balance. Take 4 centrifuge tubes and add weighed wheat, maida, barley and oats gluten powder to each tube. Add $10 \mathrm{ml}$ phosphate buffer to each tube. Set table centrifuge at $4000 \mathrm{rpm}$ for $10 \mathrm{~min}$ for centrifugation. Repeat the same procedure to get the clear supernatant. Collect $20 \mathrm{ml}$ of supernatant from each tube.

\section{Protein estimation by lowry's method}

Protein solution(Stock standard) - weigh accurately 50mg of bovine serum albumin and dissolve in distilled water and make up to $50 \mathrm{ml}$ in a standard flask. Working standard - dilute $10 \mathrm{ml}$ of stock solution to $50 \mathrm{ml}$ with distilled water in a standard flask $1 \mathrm{ml}$ of this solution contains $200 \mathrm{mg}$ of protein. Pipette out $0.2,0.4,0.6,0.8$ and $1 \mathrm{ml}$ of the working standard in to a series of test tubes. Make up the volume to $1 \mathrm{ml}$ in all the test tubes and a test with $1 \mathrm{ml}$ of distilled water serves as blank. Add $5 \mathrm{ml}$ of reagent ACS (Alkaline Copper Solution) to each tube including the blank. Mix well and allow standing for $10 \mathrm{~min}$. Then add $0.5 \mathrm{ml}$ of reagent FCR (Follin ciocalteau Reagent). Mix well and incubate at room temperature in the dark for 30min. Blue color is developed. The readings were taken at $660 \mathrm{~nm}$. Draw a standard graph and calculate amount of protein in the sample (Appendix).

Table I Explains estimation of protein concentration in wheat, barley, maida and oats flour

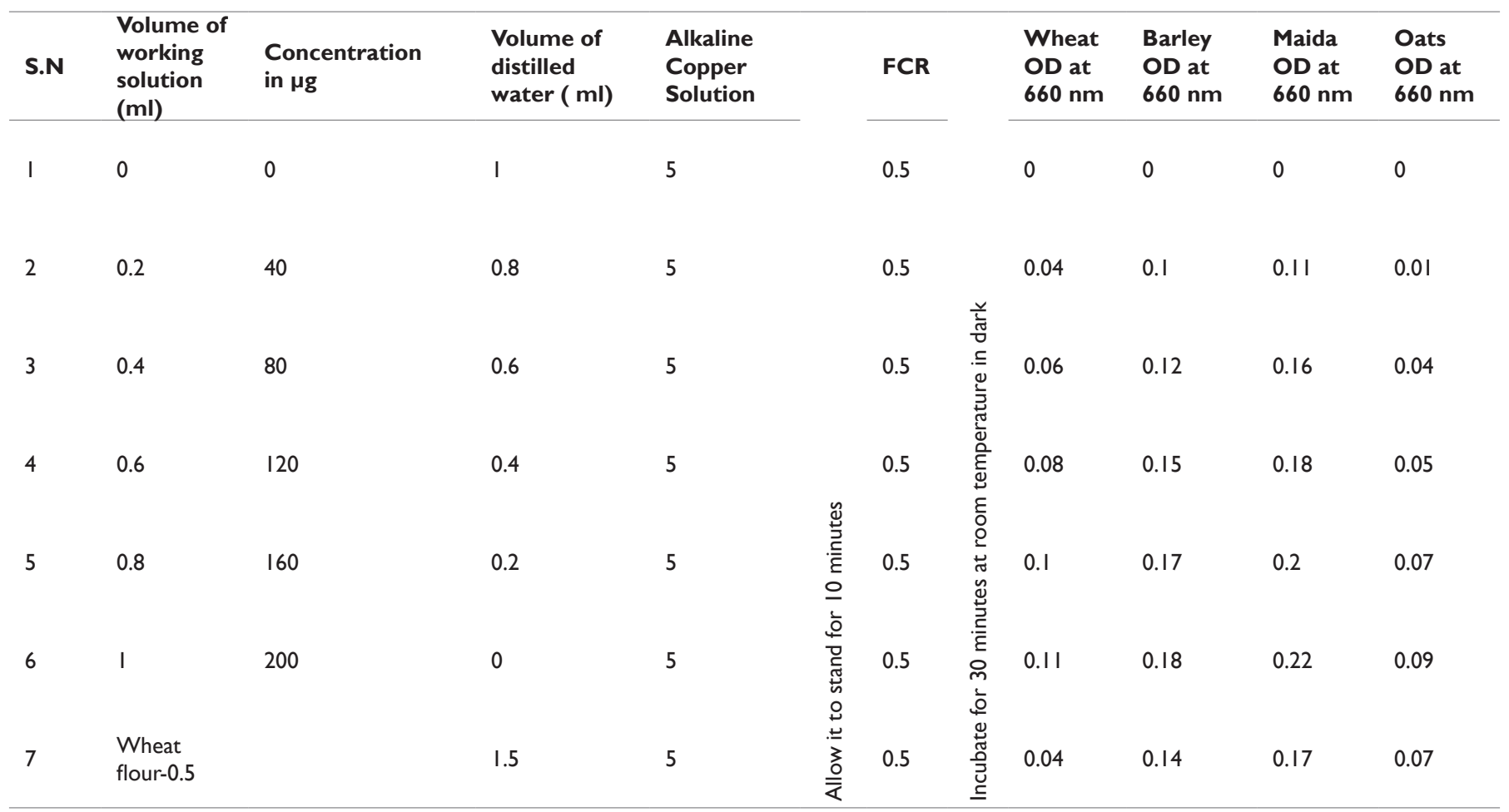


Table 2 Estimation of protein concentration in wheat, barley, maida and oats gluten

\begin{tabular}{|c|c|c|c|c|c|c|c|c|c|c|c|}
\hline S.N & $\begin{array}{l}\text { Volume Of } \\
\text { Working } \\
\text { Solution (ml) }\end{array}$ & $\begin{array}{l}\text { Concentration } \\
\text { in } \mu \mathrm{g}\end{array}$ & $\begin{array}{l}\text { Volume of } \\
\text { distilled } \\
\text { water }(\mathrm{ml})\end{array}$ & $\begin{array}{l}\text { Alkaline } \\
\text { Copper } \\
\text { Solution }\end{array}$ & & FCR & $\frac{y}{\frac{i}{d}}$ & $\begin{array}{l}\text { Wheat } \\
\text { OD at } \\
660 \mathrm{~nm}\end{array}$ & $\begin{array}{l}\text { Barley } \\
\text { OD at } \\
660 \mathrm{~nm}\end{array}$ & $\begin{array}{l}\text { Maida } \\
\text { OD at } \\
660 \mathrm{~nm}\end{array}$ & $\begin{array}{l}\text { Oats } \\
\text { OD at } \\
660 \mathrm{~nm}\end{array}$ \\
\hline I & 0 & 0 & I & 5 & & 0.5 & $\begin{array}{l}. \subseteq \\
0 \\
\stackrel{0}{\vec{Z}}\end{array}$ & 0 & 0 & 0 & 0 \\
\hline 2 & 0.2 & 40 & 0.8 & 5 & & 0.5 & 这 & 0.01 & 0.1 & 0.1 & 0.01 \\
\hline 3 & 0.4 & 80 & 0.6 & 5 & $\stackrel{\mathscr{J}}{\underline{\Xi}}$ & 0.5 & ๕ิ & 0.04 & 0.15 & 0.15 & 0.04 \\
\hline 4 & 0.6 & 120 & 0.4 & 5 & $\begin{array}{l}\cdot \overline{\bar{E}} \\
\text { 으 }\end{array}$ & 0.5 & $\begin{array}{l}\stackrel{H}{0} \\
\stackrel{y}{J}\end{array}$ & 0.05 & 0.17 & 0.17 & 0.05 \\
\hline 5 & 0.8 & 160 & 0.2 & 5 & 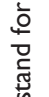 & 0.5 & 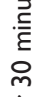 & 0.07 & 0.19 & 0.19 & 0.07 \\
\hline 6 & I & 200 & 0 & 5 & $\begin{array}{l}\tilde{s} \\
\stackrel{0}{+} \\
. \pm\end{array}$ & 0.5 & 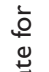 & 0.09 & 0.21 & 0.21 & 0.09 \\
\hline 7 & $\begin{array}{l}\text { Wheat } \\
\text { gluten }(0.5)\end{array}$ & & 1.5 & 5 & $\frac{3}{\bar{c}}$ & 0.5 & 苂 & 0.08 & 0.14 & 0.17 & 0.08 \\
\hline
\end{tabular}

Table 3 The estimated concentration of protein in $0.5 \mathrm{ml}$ is as given below (appendix I)

\begin{tabular}{ll}
\hline Concentration of protein in $\mathbf{0 . 5} \mathbf{m l}$ & In micro grams \\
\hline Wheat flour & 52 \\
Wheat gluten & 780 \\
Barley flour & 78 \\
Barley gluten & 117 \\
Maida flour & 97 \\
Maida gluten & 160 \\
Oats flour & 120 \\
Oats gluten & 137 \\
\hline
\end{tabular}

\section{Results and discussion}

\section{Estimation of moisture present in wheat, barley and} maida flour

Moisture percent $=\left(\mathrm{W}_{1}-\mathrm{W}_{2}\right) \mathrm{X}_{100 / \mathrm{W}_{1}-\mathrm{W}}$

$\mathrm{W}_{1}=$ Weight in gm of the dish with the material before drying.

$\mathrm{W}_{2}=$ Weight in gm of the dish with the material after drying.

$\mathrm{W}=$ Empty dish. Wheat moisture percent $=(57.5-51) \quad \mathrm{X}$ $100 / 57.5-45=52 \%$ Barley moisture percent $=(60-52) \quad X \quad 100 / 60-48$ $=66.66 \%$ Maida moisture percent $=(63.5-52.5) \times 100 / 63.5-47=66.66 \%$

Estimation of moisture present in wheat, barley and maida GlutenGluten on dry $v_{\times}$ight basis=Weight of gluten X 100 X 100/ Exact weight of sample $(100-\times$ oisture content $)$ Wheat gluten on dry weight basis $=6 \times 100 \times 100 / 50 \times(100-52)=25 \%$ Barley gluten on dry weight basis $=4 \times 100 \times 100 / 50 \quad\left(100-66_{\times} 6\right)=23.995 \%$ Maida gluten on dry weight basis $=5.5 \times 100 \times 100 / 50 \quad(100-66.66)=32.99 \%$

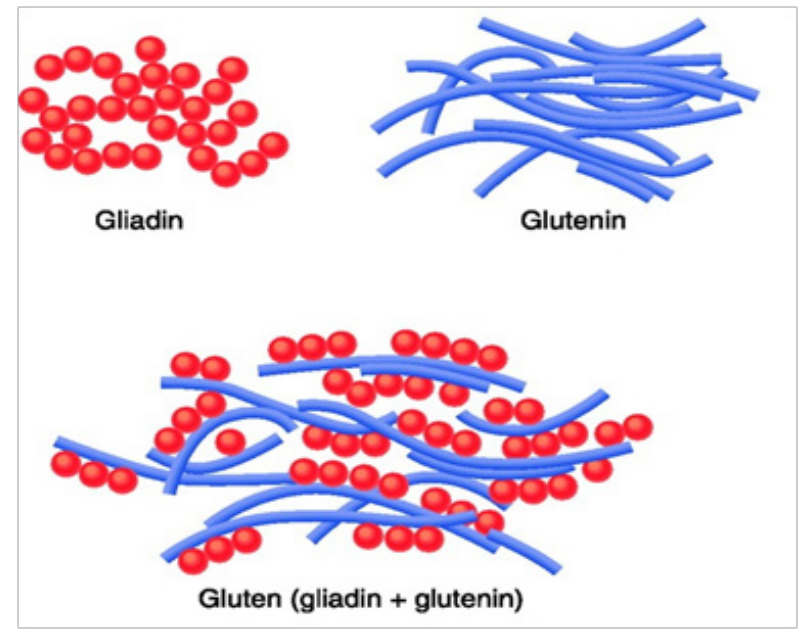

Figure I Formation of gluten.

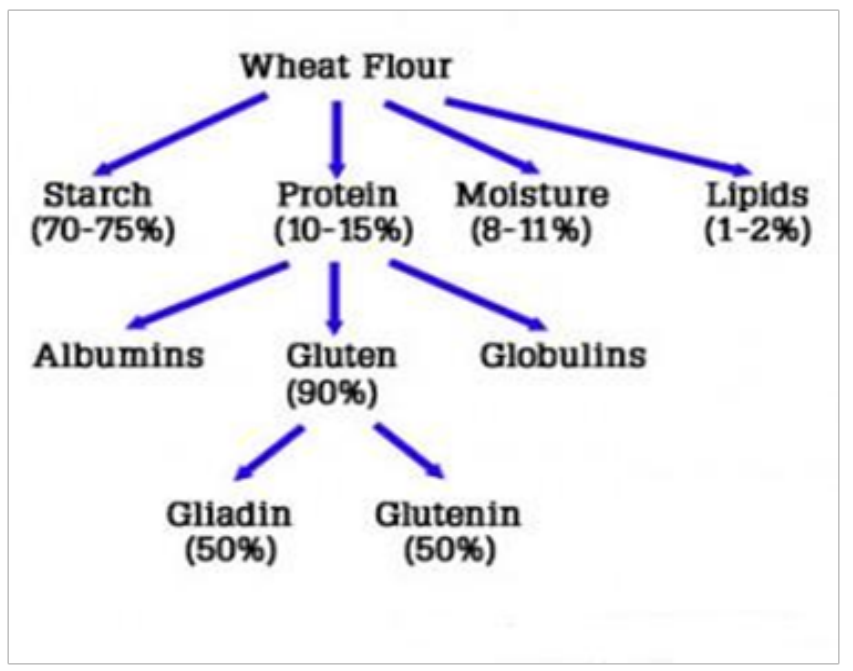

Figure 2 Different components present in a wheat flour. 


\section{Upper Jejunal Mucosal Immunopathology}

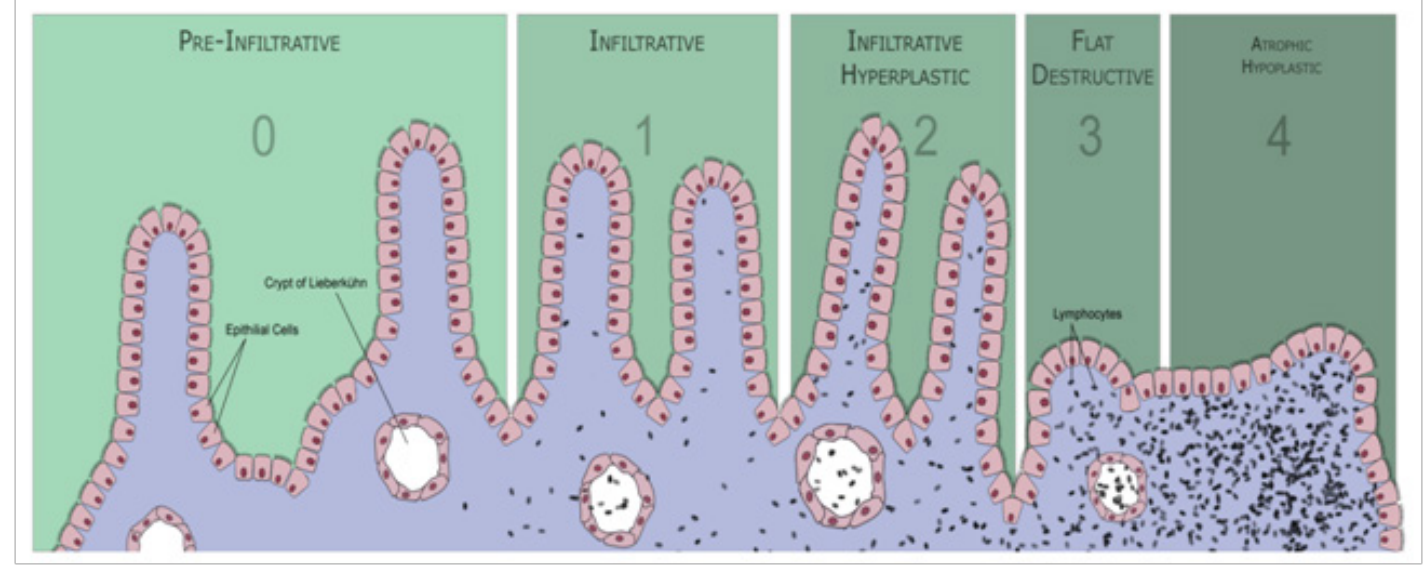

Figure 3 Diagram to show the different stages of celiac disease.

\section{Conclusion}

The present study to extract the glutens from the seed and to estimate the amount of glutens present in the seeds, common wheat, maida, barley, oats flours were collected from the local regions of Davangere, India. Gluten protein was quantified by Lowry's method which gave consistent, repeatable and reliable estimates with high sensitivity.

Gluten content was found to be more in wheat, then in maida, barley and oats respectively. The tolerable level of gluten for $\mathrm{CD}$ patient was found to be $<10 \mathrm{mg}$. As long as the value of food ingredients is based on protein content, the incentive to adulterate these materials by measures designed to inflate protein measurement will exist. The use of 19th-century crude protein measurements that do not detect many types of adulteration can be detrimental to public health, as recently demonstrated by melamine incidents. Development and implementation of more suitable protein measurement methods ones that cannot be as easily falsely manipulated have the potential not only to reduce the risk to public health but also to advance protein measurement science beyond total nitrogen based methods.

\section{Acknowledgements}

None.

\section{Conflict of interest}

The author declares that there is no conflict of interest.

\section{References}

1. Anjum FM, Khan MR, Din A, et al. Wheat gluten high molecular weight glutenin subunits structure, genetics and relation to dough elasticity. $J$ Food Sci. 2008;72(3):56-53.

2. Anson ML, Edsal JT. Advances in protein chemistry. American Journal of philosophy. 1971;2:350-351.

3. Anugrahwati H, Yamamori M, Morris AM. Effect of varying protein content and glutenin-to-gliadin ratio on the functional properties of wheat dough. Cereal Chem. 2008;76(3):389-394.
4. Atwell WA. Wheat Flour. Eagan Press Handbook Series. Amer Assn of Cereal Chemists. 2001;134p.

5. Paul St, Bariana HS, Brown GN. Breeding triple rust resistant wheat cultivars for Australia using conventional and marker-assisted selection technologies. Australian journal of Agricultural Research. 2007;58:567-587.

6. Benmoussa M, Vezina LP, Page M, et al. Genetic polymorphism in low molecular weight glutenin genes from Triticum aestivum, variety. Chinese spring. Theo Appl Gen. 2000;100(5):789-793.

7. Bradford MM. A rapid and sensitive method for the quantitation of microgram quantities of protein utilizing the principle of protein-dye binding. Anal Biochem. 1976;72:248-254.

8. Bradova J, Matejova E. Comparison of the results of SDS and chip electrophoresis of wheat storage proteins. Chromatographia. 2008;67:83-88.

9. Breiman A, Graur D. Wheat evolution. Israel Journal of Plant Science. 1995;43(2):85-98.

10. Burnouf T, Bietz JA. Rapid purification of wheat glutenin for teversedphase high-performance liquid chromotagraphy: Comparison of dimethyl sulfoxide with traditional solvents. Cereal Chemistry. $1989 ; 66: 121-127$.

11. Castillo AM, Vasil V. Rapid production of fertile transgenic plants of rye (Secale cereale). Biotechnology. 1994;12:1366-1377.

12. Chen X, Marcelo AS, Gulping Y. Development of sequence tagged site and cleaved amplified polymorphic sequence markers for wheat stripe rust resistance gene Yr5. Crop scl. 2003;43(6):2058-2064.

13. Chial HJ, Thompson H, Splittgerber AG. A special study of the charge forms of coomassie blue G. Anal Biochem. 1993;209:258-266.

14. Ciaffi M, Margiotta B, Colaprico G. Effect of high temperatures during grain filling on the amount of insoluble proteins in durum wheat. J Genet Breed. 1995;49:285-296.

15. Cloutier S, Rampitsch C, Penner GA, et al. Cloning and expression of a LMW-i glutenin gene. J Cereal Science. 2001;33: 143-154.

16. Cooke RJ, Law JR. Seed storage protein diversity in wheat varieties. Plant varieties and seeds. 1998;11:159-167. 
17. D Ovidio R, Simeone M, Masci S et al. Molecular characterization of a LMW-GS gene located on chromosome 1B and the development of primers specific for the Glu-B3 complex locus in durum wheat. Theor Appl Genet. 1994;95(7):1119-1126.

18. D Ovidio R, Marchitelli, C, Ercoli Cardelli L et al. Sequence similarity between allelic Glu-B3 genes related to quality properties of durum wheat. Theor Appl Genet. 1999;98:455-461.

19. Das AS, Mares DJ, Marshall DR. Protein composition and pentosan content in relation to dough stickiness of $1 \mathrm{~B} / 1 \mathrm{R}$ translocation wheats. Cereal Chem. 2006;65:143-149.

20. Dupuis B, Bushuk W, Sapirstein HD. Characterization of acetic acid soluble and insoluble fraction of glutenin of bread wheat. Cereal Chem. 1996; $73: 131-135$

21. Fasano A, Berti I, Gerarduzzi T, et al. Prevalence of celiac disease in atrisk and not at-risk group in the United States: a large multi center study. Arch Intern Med. 2003;163(3):286-292.

22. Graybosch RA, Morris R. An improved SDS-PAGE method for the analysis of wheat endosperm storage proteins. J Cereal Science. 1990;11:201-212.
23. Graybosch RA, Peterson CJ, Shelton DR. Genotypic and environmental modification of wheat flour protein composition in relation to endquality. Crop Sci. 1996;36:296-300.

24. Green PH, Jabri B. Coeliac disease. Lanset. 2003;362:383-389.

25. Green PH, Alaedini A, Sander HW. Mechanisms underlying celiac disease and its neurologic manifestation. 2004;43:789-791.

26. Greene FC. Analysis of possible quality related sequence variation in the D glutenin high molecular weight subunit gene of wheat, in proceedings of the $7^{\text {th }}$ international wheat genetics symposium. 1989;76:735-740.

27. Guillaumine S, Charmet G, Linossier L, et al. Colocation between a gene encoding the $\mathrm{b}$ zip factor SPA and an eQTL for a high molecular-weight subunit in wheat (Triticum astivum). Genome. 2004;47:705-713.

28. Gupta RB, Macritchie F. A rapid one-step dimensional SDS-PAGE procedure for analysis of subunit composition of glutenin in wheat. $J$ Cereal science. 1991;14(2):105-109. 